University of Rhode Island

DigitalCommons@URI

The Rhode Island Current Conditions Index

Economics

$12-2011$

\title{
Rhode Island Current Conditions Index - December 2011
}

Leonard Lardaro

University of Rhode Island, lardaro@uri.edu

Follow this and additional works at: https://digitalcommons.uri.edu/ricci

Part of the Econometrics Commons

Terms of Use

All rights reserved under copyright.

\section{Recommended Citation}

Lardaro, Leonard, "Rhode Island Current Conditions Index - December 2011" (2011). The Rhode Island Current Conditions Index. Paper 27.

https://digitalcommons.uri.edu/ricci/27

This Article is brought to you for free and open access by the Economics at DigitalCommons@URI. It has been accepted for inclusion in The Rhode Island Current Conditions Index by an authorized administrator of DigitalCommons@URI.For more information, please contact digitalcommons-group@uri.edu. 


\title{
CURRENT CONDITIONS I NDEX LEONARD LARDARO, URI
}

\author{
Available Online: http:/ / www.llardaro.com/ current.htm (NEW URL) \\ Blog: http:/ / rieconomy.blogspot.com
}

VOL $X I X$ NUMBER 1 DEC 2011
The year 2011 ended on a bit of a sour note. While Rhode Island's economy started off the year fairly well, as the Current Conditions Index registered very positive readings through April, in the months that followed Rhode Island's economy began to slip towards stall speed until November. November's CCl reading of 67 held out the prospect that we might at last be breaking out of the neutral range we had been stuck in as the year ended, and as we moved into next year. But December's $\mathrm{CCl}$ reading put an end to that speculation, at least for now.

For December, the $\mathrm{CCl}$ returned to 58 , still an expansion value, as seven of the twelve indicators improved. The good news is that Rhode Island's recovery is now 22 months old. The bad news is that the $\mathrm{CCl}$ has now failed to exceed its year-earlier value for ten consecutive months. So, the perpetual churning that occurs in any

\begin{tabular}{|l|r|r|}
\hline \multicolumn{2}{|c|}{ CCI Indicators - \% Change } \\
\hline Government Employment & -2.3 & \\
\hline US Consumer Sentiment & -6.5 & \\
\hline Single-Unit Permits & -20.3 & \\
\hline Retail Sales & 4.1 & Y \\
\hline Employment Services J obs & -1.1 & \\
\hline Priv. Serv-Prod Employment & 0.4 & Y \\
\hline Total Manufacturing Hours & 2.5 & Y \\
\hline Manufacturing Wage & 17.8 & Y \\
\hline Labor Force & -2.3 & \\
\hline Benefft Exhaustions & -17.8 & $Y$ \\
\hline New Claims & -17.0 & Y \\
\hline Unemployment Rate (change) & -0.7 & $Y$ \\
\hline \multicolumn{2}{|c|}{ Y = I mproved Value } \\
\hline
\end{tabular}

economy, with positive and negative forces interacting, continues here. The positives appear to continue holding the upper hand, as the $\mathrm{CCl}$ remains above its neutral value of 50 . But the ultimate question is how strong that hand is. While it is still too early to make a definitive call about any possible breakout in the coming months, potentially there is a hidden positive - very soon the revised labor market data for 2011 will be released. I have come to believe that these data revisions will show that Rhode Island's economy has actually been performing better than we now think. But confirmation is still needed to validate my suspicion.

Therefore, the most logical place to begin analyzing this month's results is with the five non-survey based indicators. Overall, their December performance was positive. The most noteworthy of these, Retail Sales, improved yet again $(+4.1 \%)$ capping a surprisingly strong holiday shopping season. Importantly, the recent strength in Retail Sales occurred in spite of declines in US Consumer Sentiment $(-6.5 \%)$. Better yet, on a monthly basis,
US Consumer Sentiment has now improved for four consecutive months and it appears to be gaining momentum along with more favorable national economic statistics and a rising stock market. New Claims, a leading labor market indicator that reflects layoffs, fell by 17 percent in December, following five months where it failed to improve. Benefit Exhaustions, one measure of long-term unemployment here, fell again, by 17.8 percent. This indicator has been in a downtrend since March of 2010, one month into the present recovery. Finally, Single-Unit Permits, which reflects new home construction, perhaps the most volatile of the $\mathrm{CCl}$ indicators, declined by 20.3 percent in December.

The remaining seven $\mathrm{CCl}$ indicators are all survey-based, so expect many of their values to be revised soon. Keep in mind that only their yearly changes matter for $\mathrm{CCl}$ values. Our Labor Force continued to perform very badly in December, falling by another 2.3 percent. On a monthly basis it did improve, which makes the November - December rise in our Unemployment Rate less of a negative. Total Manufacturing Hours, a mainstay of this recovery, jumped sharply $(2.5 \%)$, as the workweek rose again. The Manufacturing Wage surged again by over 17 percent in December, for those who believe in economic miracles. Employment Service J obs, a leading labor market indicator that includes "temps," fell by 1.1 percent, but this should not come as much of a surprise given its very difficult "comp" from last year. Based on the existing data, this indicator appears to have bottomed. Finally, Private Service-Producing Employment continued to grow, albeit slowly $(+0.4 \%)$, while Government Employment fell once again in December, by $2.3 \%$.

\begin{tabular}{|c|c|c|c|}
\hline \multirow{3}{*}{\multicolumn{2}{|c|}{$\begin{array}{c} \\
100 \\
90 \\
80 \\
70 \\
60 \\
50 \\
40 \\
20 \\
20 \\
10 \\
0 \\
0\end{array}$}} & \multicolumn{2}{|c|}{$\begin{array}{c}\text { December } \\
\text { Employment } \\
(S A, Y / Y)\end{array}$} \\
\hline & & Gain & 3,400 \\
\hline & & & 2,900 \\
\hline & & Net Chg & 500 \\
\hline
\end{tabular}

I always view December as "the dark side of the moon" when it comes to economic data here, since, like the astronauts, we too are almost entirely out of touch with what is actually occurring at that time. I expect positive revisions to a number of labor market indicators, but it is not clear what the magnitudes of those changes will be. I truly hope the picture that emerges is materially better than what we have come to believe, since substantial downward revisions would reflect a path far more difficult for us to manage.

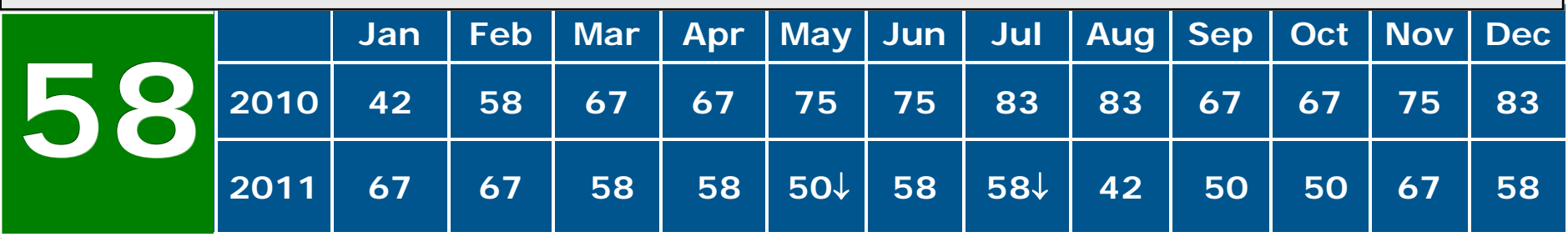

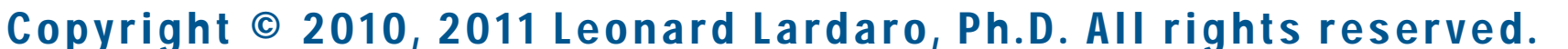

